\title{
FICÇÕES LITERÁRIAS CONTEMPORÂNEAS: EL DESPERDICIO, DE MATILDE SÁNCHEZ, AMSTERDAM, DE IAN MCEWAN E LOS INGRÁVIDOS, DE VALERIA LUISELLI
}

\author{
Graciela Ravetti \\ Submetido em 01 de maio de 2019. \\ Aceito para publicação em 26 de agosto de 2019.
}

Cadernos do IL, Porto Alegre, n. ${ }^{\circ}$ 58, outubro. p. 60-75.

\section{POLÍTICA DE DIREITO AUTORAL}

Autores que publicam nesta revista concordam com os seguintes termos:

(a) Os autores mantêm os direitos autorais e concedem à revista o direito de primeira publicação, com o trabalho simultaneamente licenciado sob a Creative Commons Attribution License, permitindo o compartilhamento do trabalho com reconhecimento da autoria do trabalho e publicação inicial nesta revista.

(b) Os autores têm autorização para assumir contratos adicionais separadamente, para distribuição não exclusiva da versão do trabalho publicada nesta revista (ex.: publicar em repositório institucional ou como capítulo de livro), com reconhecimento de autoria e publicação inicial nesta revista.

(c) Os autores têm permissão e são estimulados a publicar e distribuir seu trabalho online (ex.: em repositórios institucionais ou na sua página pessoal) a qualquer ponto antes ou durante o processo editorial, já que isso pode gerar alterações produtivas, bem como aumentar o impacto e a citação do trabalho publicado.

(d) Os autores estão conscientes de que a revista não se responsabiliza pela solicitação ou pelo pagamento de direitos autorais referentes às imagens incorporadas ao artigo. A obtenção de autorização para a publicação de imagens, de autoria do próprio autor do artigo ou de terceiros, é de responsabilidade do autor. Por esta razão, para todos os artigos que contenham imagens, o autor deve ter uma autorização do uso da imagem, sem qualquer ônus financeiro para os Cadernos do IL.

\section{POLÍTICA DE ACESSO LIVRE}

Esta revista oferece acesso livre imediato ao seu conteúdo, seguindo o princípio de que disponibilizar gratuitamente o conhecimento científico ao público proporciona sua democratização.

http://seer.ufrgs.br/cadernosdoil/index

Segunda-feira, 07 de outubro de 2019. 


\title{
FICÇÕES LITERÁRIAS CONTEMPORÂNEAS: $E L$ DESPERDICIO, DE MATILDE SÁNCHEZ ${ }^{1}$, AMSTERDAM, DE IAN MCEWAN ${ }^{2}$ E LOS INGRÁVIDOS, DE VALERIA LUISELLI $^{3}$
}

\author{
CONTEMPORARY LITERARY FICTION. $E L$ \\ DESPERDICIO, BY MATILDE SÁNCHEZ; AMSTERDAM, \\ BY IAN MCEWAN AND LOS INGRÁVIDOS, BY VALERIA \\ LUISELLI
}

Graciela Ravetti*

\begin{abstract}
RESUMO: Leitura em El desperdicio, de Matilde Sánchez (Argentina); Amsterdam, de Ian McEwan (England) e Los ingrávidos, de Valeria Luiselli (México) de pelo menos duas séries estruturais elaboradas com base nos efeitos causados por fantasmas, doenças e morte. Uma serie da organização textual que acompanha etéreos fantasmas culturais e afetivos e que deles se contamina. Outra série, a que se pauta por desperdícios, fracassos e restos de promessas de glória descumpridas para orientar suas tramas e escolher a linguagem que emprega. Duas séries que se entrecruzam e potenciam.

PALAVRAS-CHAVE: romance contemporâneo performático; Matilde Sánchez; Valéria Luiselli; Ian McEwan.
\end{abstract}

RESUMEN: Lectura en El desperdicio, de Matilde Sánchez (Argentina); Amsterdam, de Ian McEwan (England) e Los ingrávidos, de Valeria Luiselli (México) de por lo menos dos series estructurales elaboradas con base en los efectos causados por fantasmas, enfermedades y muerte. Una serie de la organización textual que acompaña etéreos fantasmas culturales y afectivos y que de ellos se contamina. Otra serie, la que se pauta por desperdicios, fracasos y restos de promesas de gloria incumplidas para orientar sus tramas y elegir el lenguaje que emplea. Dos series que se entrecruzan y se potencializan.

PALABRAS CLAVE: romance contemporâneo performático; Matilde Sánchez; Valéria Luiselli; Ian McEwan.

\section{Introdução}

Estas reflexões surgem da leitura de três romances contemporâneos a partir dos quais poderiam se estabelecer pelo menos duas séries estruturais elaboradas com base nos efeitos causados por fantasmas, doenças e morte: a da organização textual que

\footnotetext{
*Professora na Universidade Federal do Minas Gerais, doutora pela Universidade de São Paulo, bolsista de produtividade do CNPq, bolsista da Fapemig (PPM) graciela@ letras.ufmg.br

${ }^{1}$ Escritora argentina (1958), jornalista e autora de obras de ficção e ensaios. La ingratitud (romance, 1992), El Dock (romance, 1993), La canción de las ciudades (livro de viagens, 1999), El desperdicio (romance, 2007), Los daños materiales (romance, 2011).

${ }^{2}$ Escritor inglês (1948). Alguns títulos de romances: The Cement Garden (1978), Amsterdam (1998), Atonement (2001), Solar (2010), Machines Like Me (2019)

${ }^{3}$ Escritora mexicana (1983), autora de obras de ficção e de ensaios. Papeles falsos (ensaios, 2010), Los ingrávidos (romance, 2011), La historia de mis dientes (romance, 2013). Los niños perdidos. Un ensayo en cuarenta preguntas (ensaios, 2016), Lost child archives (romance, 2019).
} 
acompanha etéreos fantasmas culturais e afetivos e que deles se contamina, e a que se pauta por desperdícios, fracassos e restos de promessas de glória descumpridas para orientar suas tramas e escolher a linguagem que emprega. Duas séries que se entrecruzam e potenciam-se nesses romances sobre artistas maravilhosos, homens e mulheres, mortos vítimas de doenças cruéis e que legaram, não um produto concreto e sim um rastro de obra performática alimentada pelas lembranças esperançadas de seus admiradores e ocasionais amantes ou amigos, as delicadas marcas e reflexos que essas pessoas deixaram nos lugares pelos quais passaram.

A morte de Elena, em El desperdicio, a de Molly em Amsterdam e a de Owen em Los ingrávidos são o disparador da ficção e sua justificativa, a medida da proposição de espaços heterotópicos, ou quase heterotópicos, de acordo com a definição proposta por Michel Foucault ${ }^{4}$ e, podemos acrescentar, entre o catacrésico e o performático, entre o que é o espectro do que foi e do que provavelmente será, do corpo que se transforma pouco a pouco no outro de si até se transfigurar definitivamente pela morte. É por essas experiências de alteração de estados que as personagens se encontram no metrô ou em trens, transitam por cemitérios e crematórios, caçam lebres pelas noites, moram em quartos ou casas que concitam as mais diversas qualidades de memórias entre seus muros, enredam-se em sonhos diurnos e noturnos e não são poucos os pesadelos que se imiscuem nas suas pouco convencionais vidas cotidianas.

A espectralidade e os rastros oníricos alimentam parte importante da ficção sem com isso satisfazer a contento o anseio do leitor por saber tudo o que acontece ou de receber a descrição completa dos cenários aludidos pelas ações, pelo contrário, evidenciam fendas e aberturas sem preencher buracos negros de probabilidades ilimitadas. Esses espaços heterotópicos ostentam ao mesmo tempo um sentido metafórico e um sentido literal e servem de alicerce à rememoração das vidas dos mortos a partir dos objetos que lhes pertenceram ou que a imaginação cria como bens e bagagem para compor relatos que oscilam entre biográficos e ficcionais, realistas e fantásticos. Objetos que parecem impregnados de presságios sombrios, abrem janelas para a produção de textos ou fotografias ou partituras que podem ser vistos, lidos ou meramente imaginados na inconsistência das zonas limítrofes da percepção.

Esses lugares-outros são próprios de cada sociedade e cada sociedade tem os seus, comenta Foucault, mas a reflexão que promovem acaba tendo ressonâncias humanas gerais, tais como meditações sobre a vida/morte, o tempo, as heterocronias e a acumulação de tempo em espaços em que se ressaltam a história e a memória de caráter perturbador porque permitem visualizar impasses sem o caráter consolador das utopias; possuem relação com todo o espaço restante e com o todo social criando uma arena onde qualquer cogitação é possível; sugerem fragmentos de utopias e reservatórios da imaginação. Espaços heterotópicos como o crematório (Amsterdam), o metrô (em Los ingrávidos escolhido até como capa do livro na sua primeira edição), o cemitério ( $E l$ desperdicio e Los ingrávidos), as casas e os apartamentos que se transformam em lugares que têm a ver com os "outros" e com outros espaços e oferecem a possibilidade de vivenciar uma experiência entre o real e o irreal, entre o prosaico explicável e o estranhamento que surge dos deslizes insólitos da memória e do que, por falta de teorias convincentes, até podem cair na categoria de sobrenatural, fantástico ou maravilhoso. Visto que o tom entre macabro, algo sinistro e não poucas vezes paródico

\footnotetext{
${ }^{4}$ Em De outros espaços (1967) Des espaces autres (conferência no Cercle d'études architecturales, em 14 de março de 1967, publicado o texto em 1984. Consta em Dits et écrits, de 1984.
} 
da fantasmagoria corre em paralelo ao criticismo artístico, a inclusão de este tipo de procedimento que inclui a ironia, o humor e a ambiguidade, aceita uma aproximação ao realismo maravilhoso ou mágico, salvando as distâncias.

A esses procedimentos colocados em primeiro plano é preciso acrescentar, todavia, outros sítios da alteridade radical, os da doença, a partir dos quais os indivíduos vão ficando isolados e quase sem vontade própria e a existência deles e de seus lugares de habitação autorizam a construir uma espécie de heterotopias ambulantes - eles mesmos, seus corpos e seus habitats - que desvelam a finitude humana e os pensamentos inconvenientes a ela relacionados, os tabus e os terrores individuais e coletivos.

A epígrafe do romance de McEwan, composto por dois versos de um poema de W.H.Auden, The Crossroads: "Two friends who met here and embraced are gone,/ Each to his own mistake" ["Os amigos que aqui se encontraram e se abraçaram já partiram, /Cada qual rumo a seu próprio erro"] (McEWAN, 2012, p. 7), que poderiam servir de mote dos três livros pela força retórica que põe a ênfase no intervalo entre o real e o projetado nos cruzamentos espaciais, nos encontros em tempos distantes e nos traslados de personalidades em terrenos de sonhos e pesadelos, muitas vezes perturbadores por apagar os limites do racional e preparar o espírito para revelações ou para peripécias impossíveis de narrar em sua plenitude, para as quais só resta a sugestão e o apelo à criatividade e à erudição do leitor. A fantasmática como técnica literária tem o poder de transformar qualquer temática em descrições fenomenológicas que parecem despretensiosas e que, no entanto, exercem um peso considerável nas tramas e contribuem para fortalecer o devaneio complexo que se desdobra nas narrativas. Para tornar mais palpáveis os pesadelos, as incertezas e as conjecturas, os autores recorrem à figuração de fantasmas e aos jogos de vozes, entre a referência e a voz nem sempre confiável de autoridade do narrador, que tenta amortecer aquilo que resulta difícil de explicitar ou de transformar em imagens instrutivas e que por isso mesmo vão ficando como resíduos que não podem ser absorvidos.

Há também em cada um dos textos estudados uma obra a ser elaborada, lembrada ou reconstruída com apelo à dramaticidade performativa dos espectros que convocam futuros e passados prováveis e estabelecem filiações artísticas em jogos de resistências; uma retórica da teoria e da meta-figuração artística - literária ou musical na qual a ação de narrar - distorcida pelo efeito do foco narrativo a posteriori - e o que se narra se alimentam continuamente um a outra, ainda que cada um dos romances responda a um regime discursivo diferente e em momento algum se trate aqui de sugerir qualquer fusão de horizontes entre os textos. Clive Linley, o compositor de música clássica de Amsterdam, possuidor de um ouvido absoluto, está às voltas com a composição de uma Sinfonía do Milenio, obra encomendada com prazos fatais, e essa luta para redigir a obra serve de grande figuração da construção do romance. Assim também o romance que está escrevendo a narradora de Los ingrávidos imbrica-se em camadas com outras tentativas de elaboração de estruturas literárias, como as que remetem à vida da narradora quando morava em Nova York, às andanças de Owen alternando entre sua etapa de jovem poeta em Nova York e a do fim da vida em Filadélfia, às peripécias de Federico García Lorca em Nova York e seus supostos e possíveis encontros poéticos; às dos lances dos dois poetas juntos, podendo incluir aí até as aventuras do trio que formam com o poeta americano Louis Zukofsky; às intermitentes mas fulgurantes aparições de Ezra Pound e as referências a Hemingway, tudo isso no marco da elaboração explicita de um romance que se compraz no 
inacabamento estrutural. A narradora de El desperdicio encontra uma forma literária na qual a força da primeira pessoa vai cedendo lugar a um diálogo com os ditos e escritos da personagem Elena Arteche, amiga admirada que nunca chegou a escrever a obra que todos esperavam, mas que acaba sendo tão citada no romance que nós lemos, que suas ideias e estilo podem ser apreciados pelo leitor na liça em que ocorre uma considerável pugna de dicções que contrapõe as vozes da narradora e da personagem. No geral, tratase de lembrar e de homenagear, num tom nostálgico-elegíaco com pitadas de depreciação irônica, de reconhecer e recuperar, mas também de devanear com as implicações referenciais.

Escritores e artistas reais são citados como para dar volume às descrições e ideias apresentadas, como espíritos errantes que vão se apropriando dos vivos e oferecendo propostas que, ao lado de pressupostos canônicos, são recebidas pelos narradores e protagonistas dos romances em tela como elementos conformadores de textos cuja experimentalidade enreda-se numa zona cinzenta na qual se assentam os labirintos temporais e o apelo a uma certa mimese - a música reverberando os sons da natureza e a reminiscência da amante e suas performances, a narrativa tomando conta de uma biografia que tenta fazer a devida justiça a uma amiga brilhante, as agruras da vida cotidiana de uma escritora que se projeta como narradora e como personagem enquanto recebe a inspiração na forma de fantasmas percorrendo a casa - que, se somado tudo ao recorrente uso de lugares heterotópicos, converge para aprofundar ambiguidades e destaca a instabilidade figurativa que compõe os textos e que configura a hipótese de uma atualização do modo realista na contemporaneidade. Ezra Pound, Gilberto Owen, Federico García Lorca, Nella Larsen, Louis Zukofsky, Salvador Novo e a revista mexicana Contemporáneos em Los ingrávidos; Bach, Stravinsky, Mozart, Schubert, Paul McCartney, Vaughan Williams, John Lennon, Yoko Ono, Jimi Hendrix, Beethoven, Dylan Thomas e outros em Amsterdam; personagens reais e outros mais ou menos reconhecíveis no romance à clef que pretende ser El desperdício, em um jogo dicotómico entre realidade e imaginação, cujos limites entre ilusão e invenção ficam esvaídos, como rastros que se excluem uns aos outros.

\section{Um método de escrita entre fantasmas e imposturas}

Los ingrávidos inicia-se com a epígrafe de A Cabala que adverte sobre o cuidado que se deve ter ao brincar com fantasmas pelo risco de se transformar em um; fala-se da possibilidade de morrer muitas vezes, porém, continuar vivendo, experiências essas pelas que passam a narradora - quem desde jovem mantém uma quevediana conversação com os defuntos e gosta de frequentar o cemitério para ler e pensar - e o escritor mexicano da primeira metade do século XX que ela investiga. Essa narradora, que comanda o relato inicial do romance, viaja entre épocas. A da primeira juventude, quando trabalhava em uma pequena editora em Nova York, oportunidade que aproveita para fraudar um documento que lhe serve para promover um autor mexicano quase desconhecido no âmbito internacional, Gilberto Owen (1904-1952), que colaborou na revista Contemporáneos, até a da vida de casada, o presente da narração, com dois filhos e um marido na Cidade do México em uma casa que parece albergar um fantasma. Trata-se da mesma pessoa, em duas etapas da vida e em dois cenários diferentes, apresentada via discurso indireto livre. 
Também personagem, a narradora está escrevendo um romance no qual se desenha como uma pesquisadora que persegue de forma obsessiva a vida de Gilberto Owen para escrever sua biografia, encontrar um método criativo para trabalhar na própria obra e se projetar nela de alguma forma. Seu excêntrico modo de fichamento consiste em escrever frases em post-it com informações, ideias e fragmentos que poderiam ser de autoria de Owen ou consistir em meros simulacros, cópias de fragmentos ou sentenças motivadoras. Esse procedimento funciona como uma estratégia irônica que sugere a meticulosa fabricação de uma falsa referência para a investigadora, ainda que não para o leitor, que testemunha o quase delírio referencialista. Ocorre, então, uma hilária falsa mimese que põe em crise a própria objetividade quando os papéis com as frases vão sendo pendurados na árvore seca, que supostamente pertenceu a Owen e que funciona como um fetiche no apartamento da narradora, os textos breves que são transcritos no texto maior e definitivo do romance acabam operando como citações, algo assim como se se criasse primeiro um artefato para depois copiá-lo, instituindo um modo peculiar de realismo performático.

O espaço narrativo, cuja estrutura provoca o efeito de estar recuperando o momento performático da escrita do texto à medida que se escreve, oscila entre Cidade do México (presente), Nova York (o passado da narradora e o passado de Owen, anos 1928-1930) e Filadélfia (a juventude de Owen). Nessa heterocronia misturam-se a vida afetiva da narradora, cujas emoções são as que lhe marcam o rumo da vida, da pesquisa e da escrita ficcional; a vida sentimental e a intelectual, que essa mesma narradora imagina ser a evolução de Owen e seus improváveis encontros artísticos, ainda que possíveis, mas nunca documentados, Encontros entre ele, García Lorca e Louis Zukofsky, que moravam em Nova York nesses anos do crack financeiro.

O que de início parecer ser uma simples impostura para garantir a permanência na editora para a qual trabalha, transforma-se em uma obsessão pelos textos de Owen ou sobre ele que a conduz a especular sobre a especificidade da vida do escritor mexicano nos Estados Unidos durante aqueles anos. É assim que decide falsificar um texto que acaba precipitando o desastroso final de sua incipiente carreira como editora em Nova York. Essa obstinação é também a que a inspira, anos mais tarde e já sendo mãe de dois filhos e com um casamento em crise, na Cidade do México, a escrever um romance no qual sua voz vai sofrendo uma radical, ainda que quase intangível, plasticidade ou sendo vítima de uma verdadeira usurpação pela voz de Owen, que toma as rédeas da narração e se apropria do tom e da temática. Se em Los ingrávidos há uma construção em espelho - as mesmas cenas contadas dos diversos pontos de vista das personagens -, como ocorre na emblemática cena do trem, isso se consegue pela construção de um loop temporal que faz com que a narradora passe a ser uma criação de Owen assim como Owen é uma construção da narradora. No ápice da fantasmagoria, as duas personagens passam a morar no mesmo apartamento, cada um no seu tempo e sem se encontrar e, afinal, fica a quase certeza de que pode ser Owen a assombração que habita a casa da Cidade do México, assim como a narradora pode ser o espectro que mora no apartamento de Owen em Nova York.

Os breves fragmentos de extensão variada, que se sucedem para compor a estrutura, possuem uma cadência musical e significativa que, no início, dão forma a um rítmico vaivém entre o presente da mulher, que só consegue escrever um "romance silencioso para não despertar as crianças", e seu passado, quando era muito jovem, de pernas magras e atléticas e andava pelas bibliotecas procurando o "próximo Bolaño" para que a pequena editorial na qual trabalhava o publicasse. Progressivamente, e à 
medida que cresce o interesse da jovem pela escrita e pela vida do poeta mexicano Gilberto Owen, o leitor percebe que a voz que narra é já a de Owen e não mais a da narradora inicial. Os fantasmas da literatura povoam suas páginas. Tú puedes recordar el futuro, disse Homer Collyer a Owen. E sim, é o que ocorre. Owen vê a escritora do século XXI exatamente nas ações e nos cenários nos quais ela o viu. Escrever romances, explica Homer a Owen, é dobrar o tempo ou, melhor, congelar o tempo sem deter o movimento das coisas, que seria pura e simplesmente equivalente a esboçar um argumento em favor de pensar o produto literário como um objeto a mais no cenário real, uma espécie de recorte de um certo estado de coisas. Um argumento a favor do realismo performático como procedimento essencial da construção do romance.

A escritora e principal narradora está procurando um método de escrita que faça com que a ficção comece no movimento de modificar a realidade e não ao contrário, razão pela qual decide ir escrevendo sobre o que aconteceu e sobre o que não sucedeu embora esteja no horizonte do possível. Pretende (des)escrever uma história em um arquivo, urdir uma trama diferente em outro e depois transformar tudo em um romance fragmentado cujo esquema narrativo parece acompanhar o modelo do metrô, com suas múltiplas estações, suas panes, suas acelerações repentinas, suas zonas escuras, ao todo, um labirinto espacial emoldurado por uma bolha de tempo congelado. Para a narradora, o metrô convida ao encontro com os mortos e com o passado; para Owen, o subterrâneo possibilita alcançar a quarta dimensão do tempo. Essa reflexão é a que dispara a força da outra narrativa que se desenha em espelho: a de Owen nos anos de 1920.

\section{Retóricas da morte}

El desperdicio abre-se para o leitor com uma apresentação, entre erudita e irônica, do cemitério de Pirovano, a cidade de Elena no interior da Argentina, que compara o setor de panteões de estilo neoclássico e as galerias de nichos a uma biblioteca onde só poderia se esperar encontrar escritores católicos, discorre sobre a finitude da vida dando atenção especialmente à das crianças e jovens, faz referência aos poetas de cemitério, antecessores dos novelistas góticos e até cita a Elegia de Thomas Gray, tudo isso para justificar que esse prólogo divagante não é mais que uma moldura de eloquência incumbida de demorar o momento do advento brutal do cadáver em seu ataúde, para amenizar o impacto da dor que a morte de Elena Arteche causou nos amigos aí reunidos ou para valorizar a chocante e turvadora imagem da morte em toda sua crueza fazendo contraponto invertido a qualquer retórica.

O romance de Sánchez está dividido em três partes: A idade da comédia, O período gótico e Barroco fúnebre. O texto inicia-se com a alusão à heterotopia do cemitério, visível desde longe pelos lúgubres álamos que se enxergam à distância e que compõem a fracassada alameda que está na entrada da cidade do interior, Pirovano, aonde se dirige a narradora para sepultar a amiga. Entre as lembranças que se afastam e que só podem ser observadas pelos sujeitos convertidos em espectadores e os esquecimentos triunfais que se tornam segredos de família estão aqueles fatos que foram rasurados por completo e os outros, os que se impuseram como lembranças únicas, inapagáveis, que agem como feridas que não cicatrizam.

Utilizando a primeira pessoa do singular, a narradora de El desperdicio recorre a referências intimistas relativas a escritores que participavam do grupo de amigos intelectuais em Buenos Aires, décadas antes da morte de Elena. O procedimento 
recorrente é compor um bloco de tempo que leva o nome de Elena, como se se tratasse de um lugar e um tempo passado que permanece vivo no presente, superpostos os tempos, assim como Elena pode ser nomeada Helen ou Elenita, Lenu ou Leni, Vasca, E., todos nomes que revelam o estado de espírito da personagem em diversas circunstâncias de sua vida, seus encontros amorosos e de amizade, e retratam os permanentes esforços de reconstrução subjetiva que empreende a personagem em diversos momentos de sua existência.

Passando em revista três décadas da vida de Elena/Helen/E., a narradora afirma que a passagem que levou uma moça do interior a converter-se em uma sofisticada e excepcional leitora de literatura e em crítica de teoria literária só se explica pela influência da época e do ambiente, com ênfase na política e destaque para as filiações literárias e cinematográficas. Helen escreve fecundos ensaios breves na década de 1980, quatrocentas páginas por ano, com foco no conceito de ostranenie que os formalistas russos elaboraram nas primeiras décadas do século XX e que ela aplicava a tudo. Esses escritos foram canibalizados, usurpados numa impostura infindável, numa torrente de apropriações que rasuravam a autoria de Elena e a disseminavam no que poderia ser chamado de pensamento da época na área de estudos da literatura. Explica a narradora que, pela forte mudança que sofreram os modos de leitura, o conteúdo do que se lia e a operacionalidade do circuito da proliferação das fotocópias no âmbito universitário, instaurou-se uma maquinaria cultural que era vista como uma forma indireta de fazer política já que essa indústria das fotocópias constituía a principal fonte de financiamento dos centros de estudantes e, por tabela, do movimento estudantil dos anos de 1970 e 1980 na Argentina.

Os originais desses textos devotados ao estruturalismo de autoria de Elena acabaram perdidos e disseminados na maré de papéis impressos produzidos e consumidos nos meios universitários, submergidos em massas de bibliografia pirata, mecanismo onívoro, enxurrada coletiva e anônima. As ideias de Elena, desde esta perspectiva, foram cruciais para alimentar o pensamento público, roubadas sem pudor pelos professores que, sem dar crédito à autora, ampliavam e reciclavam suas ideias, favorecidos talvez pelo hermetismo dos escritos. O desperdício do título pode se referir a que Elena morre sem deixar uma obra completa, aquele importante e grande livro que lhe daria o sucesso definitivo e documentado no seu ambiente, potenciaria o impacto que ela já tinha no subsolo da cultura e a transformaria no grande nome da crítica literária local. Contudo, o perfil performático de Elena a impelia a gostar de sua aura secreta, a cultivar um estilo fundamentado no fracasso e na discrepância, em um ambiente onde publicar era quase impossível e menos sendo mulher.

O fracasso intelectual, social e financeiro e a dissonância de Elena - entre o suposto prometido e o resultado final da vida produtiva - funcionam como argumentos explícitos da narradora, que mantém até o final uma clara distância emocional de sua personagem. Como consequência desse descompasso, a narradora não parece conseguir entender que é factível supor que os caminhos escolhidos pela amiga tenham respondido a outros parâmetros, critérios diferentes aos seus, irremediavelmente perdidos para uma inteligência literária e vital mais mesquinha, como é a sua, que não alcança a abranger, apesar da admiração confessa e da proximidade, a amplitude e a significação das batalhas livradas por sua personagem em sua implacável negação a corresponder às ilusões que as pessoas de sua geração alimentavam sobre a concretização de uma obra que justificasse a admiração de que era objeto. 
A narrativa sobre Elena que a narradora vai urdindo rejeita o tom e o conteúdo elegíaco, apesar do título da primeira parte, e para isso põe travas à suposta obrigada triste lamentação funerária, de acordo com certas convenções tradicionais (KANZEPOLSKY, 2013). Nessa tessitura, a narradora passa de enaltecer os dotes excepcionais de Elena e seu brilho intelectual, a compará-la com uma louca mendicante que vaga à procura de cigarros, vítima de uma pretensa precariedade emocional que a compele a se despedaçar entre amantes torpes e desprezíveis que depenam invariavelmente sua casa e sua biblioteca, roubando-lhe livros valiosos e outros objetos.

O detonante da narração, como já se disse páginas atrás, é a morte de Elena que duplica o destino de sua irmã, Carmen, cujo padecimento físico começa a ser narrado nas primeiras páginas e que é projetado em uma frase que diz tudo sobre o status da doença na sociedade, da perspectiva dos que observam a sina da família: sangue envenenado. Com a doença e a morte da irmã, a narradora explica que assim acabou um ciclo de comédia para Helen. O processo é assimilado ao que sucede com a terra, o campo, o país, que estaria perdendo seu apelo lírico para entrar nos périplos bancários e circuitos financeiros enquanto a cidade transforma-se em uma canteira de desperdícios. Com essa virada retórica, Sánchez acha o pretexto que precisava para ampliar o conceito de desperdício e aprofundar a ambiguidade do título. Ao trazer à tona variações de acepção para desperdício confirma-se que a remissão repentina a outras referências - políticas, ambientais e sociais -, menos tangenciais em sentido lato que quando referidas à uma obra não escrita, desorganiza uma possível totalização do sentido do romance. No obstante, ao abrir fendas que impedem uma leitura cerrada e unívoca, abre-se uma distância considerável entre exemplos e argumento central que dilui o método de escrita estrito e centrado que foi proposto na primeira parte do romance, porque refrata, se bem que por vezes de forma bastante superficial, vários temas cujas implicações e desenvolvimento tímido acabam funcionando como excertos sem ligação forte o suficiente para justificar certas digressões narrativas ou sobreposições de fragmentos, como é o caso do episódio da caça de lebres e a menção ao ano 2001, o "ano negro", de triste memória na Argentina, mas que parece funcionar como uma remissão metafórica sem demasiadas consequências significativas para o relato.

O fim da comédia dá início ao período gótico. Elena, que havia nascido e sido criada entre uma cidade do interior e a vida de campo, passou seus anos de comédia entre Buenos Aires e Mar del Plata, mas no período gótico sofre uma "conversão rural", um reencontro com o tempo perdido que a leva a entrar de cheio na nostalgia e a por em marcha uma mudança radical, no mencionado "ano negro", 2001, na Argentina, na tentativa de conferir algum lastro de política explícita ao texto. Nesta parte já há referências à próxima, denominada barroco fúnebre, em alusão a um conceito de Roland Barthes que associou o kitsch a um barroco fúnebre, talvez porque é a esta altura da narrativa que faz sua aparição o fantasma de Carmen, a irmã morta. Como em Los ingrávidos, um fantasma nostálgico percorre a casa. É nesta seção que a escrita da narradora se alterna com a de Elena, utilizando para isso fragmentos de suas cartas ou transcrições de sua voz falando sobre o fantasma da irmã e até reivindicando uma ciência dos espectros.

Pouco a pouco as observações sobre os espectros vão se contaminando de realismo, afirma a narradora, e alegorias políticas se insinuam no que vai se transformando em uma dicção dialogada na qual duas narradoras se intercalam, e a estranheza que emana dos fragmentos recortados e superpostos cria uma perturbação, 
entre patética e melancólica, que funciona como a amarga ressonância de um passado trágico, a morte da amiga, que opera também como um caudal de comprovações das teses da narradora sobre a personagem.

Em El desperdicio há uma operação de abstração, generalização e simplificação assim como uma construção irônica e impiedosa quase permanente que foge bastante ao que são as novas tendências literárias do que chamo realismo performático, que dão valor a certas tendências filosóficas, como a de Martha Nussbaum, nas que se valoriza a incisiva penetração da literatura na pesquisa sobre o indivíduo, o exaustivo aprofundamento nas propriedades da linguagem com o intuito de dar conta da consciência e da ressonância detalhada das experiências pessoais na articulação de seus mundos interno e externo.

No desfecho, a narradora reconhece não ter como saber se o rumo dos acontecimentos que está concluindo de narrar é fiel ao que efetivamente sucedeu e afirma que o que foi contado com tanta segurança e detalhes parece-lhe agora uma espécie de distração, uma forma de desviar a mente a procura incessante de algum fato oculto, mas que prenuncia algo de essencial. Ela, a fiel testemunha, sente-se às vezes ainda no cemitério, importunada pelas imagens mortuárias que subsistem como antessala preparatória para um sonho no qual Elena e sua irmã passeiam pela cidade funerária, ouvindo os sons das escopetas e dando espaço às mais fantasiosas cenas, imaginárias ou oníricas, que põem em xeque até a própria categoria do romance, que poderia vir a ser qualificado como de ficção total, um completo invento, pese ao declarado tom biográfico que a narradora insistiu em remarcar.

Se a capacidade de distanciar-se dos fatos é fundamental para criar um relato literário e a ostranenie sobre a que Elena reflete durante toda sua vida é apresentada como a atribuição maior da arte, porque o habitual ou corrente pode ser revelado de forma inédita pelo criador artístico, a conclusão fantasmagórica do romance funciona como uma armadilha que aciona os limites das hiperbólicas exigências e condicionamentos que coagem a criação literária. Entre a realidade e o sonho, a mimese e a ficção, a objetividade e o artifício, a fantasmagoria surge tão poderosamente ligada à representação que acaba sugerindo que tudo aquilo que tanto custou construir ao longo do romance, desagua numa iluminação espectral que pretende derrubar num golpe tudo o que a voz narrativa elaborou, provocando assim que o ato da escrita se recurve sobre si mesmo.

\section{Realismo macabro}

O narrador de Amsterdam acompanha os discursos interiores e as perspectivas de observação conflitantes dos dois amigos depois da morte de Molly, perseguidos ambos pelas lembranças de seus próprios erros, rememorações inconvenientes para entender ou justificar o presente, razão pela qual lutam internamente para não deixar que a memória trabalhe livremente na exploração do passado, evitando, assim, abandonar-se à contemplação de flashes de momentos do passado para, em movimento contrário, entregar-se a reconstruir a própria história rasurando lembranças intempestivas que obstaculizam a elaboração cuidadosa de miragens autocomplacentes de si mesmos, sem confirmação referencial, nas quais se veem inocentes e vítimas das circunstâncias. 
Em Amsterdam, a cena inicial transcorre em um crematório, com a cerimônia não religiosa realizada por ocasião da morte de Molly, um evento social que atrai muita gente, na qual estão presentes o marido e três ex-amantes da mulher: Clive Linley, o compositor; Vernon Halliday, o editor de jornal; e Julian Garmony, o ministro das Relações Internacionais da Inglaterra. $\mathrm{Na}$ cena final, os corpos dos dois protagonistas viajam de volta a Inglaterra em avião, silenciadas assim as vozes cujas elucubrações interiores conduziram a narração até então.

Em paralelo às investidas de um sobrenatural entre traumático e saudoso, nos três romances - particularmente exitosas em McEwan - um realismo técnico tenta dar credibilidade ao relato acompanhando as reflexões das personagens em seus tateios, movidos a emoções e mesquinharias, transeuntes numa longa curva de ascensão seguida de uma anunciada queda, ao mesmo tempo rápida e fatal, que acaba conferindo ao traçado geral do romance, de estrutura em paralelo - ascensão e queda de Clive, ascensão e queda de Vernon -, uma aura de catarse coletiva. No acelerado último capítulo, o leitor acompanha os comentários do narrador na tentativa de elaborar um irônico plano geral, da perspectiva de vários personagens, para dar conta das cinzas que restaram das reputações dos dois homens que agora serão também os atores principais de seus próprios funerais.

Numa combinação de arrogância e destempero, autoavaliações ensandecidas e isolamento levados às últimas consequências, no que logo saberemos ser o cenário crepuscular de suas vidas, as duas personagens - Clive e Vernon - são conduzidas no desenho de um movimento de ascensão que revela o intervalo de tempo - do velório da amiga às suas próprias exéquias - em que tentam alcançar e ocupar o topo de suas áreas de atuação profissional, vacilando entre agoniantes equívocos, aberrações e inconsistências argumentativas que anunciam o desastre que as escolhas assim geradas irão fatalmente produzir.

A morte da amiga e amante dos protagonistas (Molly, a musa, fotógrafa, jardineira e escritora), as posteriores angústias pela criação musical (Clive, o compositor), as dores e encruzilhadas éticas do ambicioso editor de periódico (Vernon, o jornalista) e a ruína dos dois tentando perscrutar o presente para se acomodar no futuro são alguns dos temas cruciais de Amsterdam. A fama de macabro que acompanha a McEwan confirma-se neste romance que é uma espécie de narrativa de uma vingança sobre-humana e perturbadora, ainda que satírica, que se concreta, em parte, com a ajuda entre sarcástica e farsesca do marido de Molly, George, o único sobrevivente da peripécia, que inclui um pacto de eutanásia entre os dois amigos que acaba sendo o cenário e a oportunidade para um duplo assassinato.

Depois do movimento de ascensão e queda dos protagonistas, o mundo permanece tão sólido quanto sempre foi, tanto que George Lane refocila-se ante a ideia de preparar um funeral, tal como o que organizou no início do romance, agora para seus adversários, outrora invencíveis, no amor de Molly. Há também a destruição da carreira do outro amante de Molly, o atual Secretário de Estado, Julian Garmony, vítima de uma intriga com base em fotos comprometedoras de Julian tomadas por Molly, entregadas por George a Vernon, para serem publicadas no jornal e assim arruinar as pretensões de elevação política de Julian, que aspira a ser Primeiro Ministro. Num breve resumo como esse pode parecer que as consequências do escândalo midiático causado pela revelação das fotografias, que mostram o ministro em roupas de mulher posando para a câmera, resultariam catastróficas para o político. No entanto, a resposta social à divulgação da intimidade de um ator político de importância no âmbito nacional traça, pelo contrário, 
a progressiva e inexorável derrota de Vernon, o editor, em seu cego e impetuoso avanço em direção ao suicídio social, abismo anunciado embora o personagem faça questão de mal- interpretar os signos que se lhe apresentam. Assim, a transgressão ética do editor dá lugar a uma série de cenas e discursos pedagógicos sobre os perigos derivados da quebra de decoro jornalístico e os limiares morais intransponíveis e, sobretudo, imperdoáveis.

Enquanto Vernon tenta aumentar a fatal queda de vendas do periódico, apelando ao sensacionalismo com a publicação das fotos privadas do político, manobra que culmina em um estrondoso fracasso, Clive empenha-se em concluir sua sinfonia do novo milênio, procurando inspiração na natureza valendo-se de seu ouvido absoluto, mas tudo converge também para arruinar a peça que é recebida como um plágio da Ode à alegria de Beethoven. O leitor acompanha as agruras e os momentos inspiradores da criação musical de Clive e, no desfecho, confronta-se com a descoberta do plágio vergonhoso. A sinfonia, nas divagações de Clive, viria a ser uma elegia do século XX, com uma melodia reconhecível e perdurável que daria conta da genialidade do autor, ele mesmo, ao mesmo tempo que se converteria em uma espécie de pranto pela crueldade insensata da época. Crítico feroz do projeto modernista, Clive reflete sobre a história da música dando relevância à melodia, à harmonia e ao ritmo que, a seu ver, longe de serem âncoras evidentes do conservadorismo musical seriam, em verdade, elementos destacados para a inovação. Seu ambicioso projeto e sua luta teórico-ideológica consiste em tentar resgatar a comunicabilidade essencial da música, sequestrada pelos "donos da verdade", quer dizer, os célebres autores de música atonal e aleatória, das séries dodecafônicas, da música eletrônica, que, na contemporaneidade, ocupam o lugar sagrado de sacerdotes de uma ortodoxia hegemônica.

Nessas redes de acontecimentos e reflexões, os desiludidos personagens, imersos em sinistros esquemas, resultados de escolhas desatinadas e de brigas desestabilizadoras, culminam em estrepitosos fracassos e suas vidas se mostram por completo viciadas pelos seus ímpetos desregrados e a incapacidade para amenizar as culpas. Como dois oportunistas que são, em seus discursos interiores constroem relatos que revelam dilemas morais em situações pouco críveis: ajudar ou não a alguém que está em grave perigo - Clive -, ou decidir se usar ou não fotos privadas para atacar reputações via o jornal - Vernon. As decisões que tomam as justificam com a combinatória de argumentos desvairados produzidos pelo alienado autoconvencimento de estar cumprindo missões de importância cultural.

Considerando-se a força do conceito de heterotopia de Foucault neste romance, além de tudo o que está relacionado com a doença, a morte e a cremação de Molly, no capítulo 1 da III parte há uma passagem especialmente interessante na qual se descreve a viagem que empreende Clive, empacado na sua obra, de Londres ao Lake District, em busca de inspiração. Nesse fragmento da narrativa, o músico percebe que, quando permanecia protegido no refúgio que é sua casa em Londres, a imaginação lhe permitia pensar a civilização como a somatória de todas as artes, uma bela utopia que acalentava sua percepção otimista e estetizada da realidade. Essa quimera desmancha-se, entretanto, em uma súbita visão da paisagem que enxerga através da janela do trem, como se de repente observasse uma heterotopia incomensurável: a natureza tal como realmente ficou depois da interferência humana, deixando à mostra os restos de sucessivas utopias, os vestígios de projetos desvirtuados ou mal concebidos. O que seriam, se não, as construções sem graça disseminadas a esmo, as fábricas de produtos sem valor lembrando a alienação consumista, as estradas intermináveis que obstruem e 
pervertem a arquitetura natural do planeta? Tudo está aí, a sua frente, evidenciando o fracasso da obra humana, errada desde o começo, cujos efeitos produzidos contribuem com a formação dessa imensa heterotopia, na contemporaneidade, marcada pelas ruínas da sucessão histórica de malfeitos humanos, como se nada do sublime criado pela arte e o design tivesse de fato existido, a paisagem planetária na qual a maioria da população é obrigada a habitar, pese à repulsa que concita.

A morte de Molly dispara em Vernon o senso de ausência ou, o que é o mesmo, a sensação de não-existência, o que combina muito bem com a pintura que o irônico narrador faz dele: uma nulidade, um incompetente jornalista alçado a editor por uma conjuntura de desastrosas coincidências. Como em Los ingrávidos, ele convive com sua própria morte, uma situação de todo catacrésica, para a qual não existem palavras que a definam. McEwan recorre a vários tipos de descrições e de imagens narrativas para dar conta dessa fantasmagoria, algumas tradicionais como a de o indivíduo se olhando no espelho - uma heterotopia que podemos já considerar clássica - sem se reconhecer, e outras mais originais como a de sentir que um processo está ocorrendo no próprio cérebro, afetando o hemistíquio esquerdo e produzindo, no direito, uma sensação sombria ou fantasmal.

Parte importante da força retórica da narração de Amsterdam manifesta-se na zona de atrito incessante entre referência e mundo instaurado na interioridade dos sujeitos. Todavia, o desfecho toma a forma de um clímax tragicómico shakespeariano com os protagonistas mortos e um capítulo final que consiste em uma espécie de sumário irônico, da perspectiva do triunfante George, rememorando tudo o acontecido, o que parece revelar um esforço para abolir tudo o que de heroico pode ter tido a própria narrativa dos feitos dos protagonistas para destacar o melancólico fracasso dos dois. Esse procedimento contribui para construir um ponto de estabilidade ou mesmo uma zona morta a partir da qual o narrador pode colocar bruscamente entre parênteses o pormenorizado relato do fragmento de vida dos protagonistas desde a morte de Molly para clausurar a série de derrotas e frustrações que são a marca registrada dos protagonistas, Clive e Vernon.

\section{Conclusões}

... as a dead souls babbling at the edge of a dream.

(... como o som de almas mortas tagarelando nos limites de um sonho.) (Don DeLillo, White noise)

Há, nos três romances comentados neste trabalho que ora se encerra, salvando as distâncias e marcadas as diferenças de cada livro em relação aos outros, uma preocupação direta com a possibilidade de refletir sobre se as expressões artísticas ou literárias podem ou não revelar algo sobre a consciência quando dizem algo sobre si mesmas ou sobre o mundo. A arte de compor um romance ou uma sinfonia, um poema, um ensaio teórico ou até a edição de um jornal, em parte, consiste em transformar em palavras, em notações musicais ou em imagens visuais o que pode ser percebido pelo olhar, a escuta e a exploração intelectual do mundo, assim como sua projeção em imagens que são ou virão a ser reconhecíveis e interpretáveis pelos receptores. Se essa espécie de transposição não pretende ser uma descrição completa de determinadas 
sequências mas, pelo menos, tenciona recolher ecos e ressonâncias, dá lugar a suspeitar da possibilidade de existência de uma espécie de luz de entendimento a ser recebida na leitura, tal como se existisse uma linha divisória entre as ideias apreendidas em plena luz do dia e lidas nos documentos e livros ou músicas e aquelas que espreitam nas sombras e dobradiças da percepção. Essa aparente desordem dos sentidos em determinados momentos torna o fantasmático em realidade e a realidade em espectral, confundindo e desencontrando sobremaneira ambas esferas até o ponto de resultar difícil ponderar os limites de cada um e que, se bem esses fragmentos podem ser lidos como procedimentos inovadores e vivificantes na narrativa contemporânea, sabe-se que têm uma longa e profícua tradição que os respaldam e que sem dúvida estão aí, entre outras finalidades, para lembrar ao leitor que está no território da ficção. À fantasmagoria somam-se as referências ao estudo e à pesquisa performática, à procura de métodos de trabalho de composição - musical ou escrita, ficcional ou teórica - e tudo acaba engendrando uma massa de textos que flutua sobre um vasto território subliminal que é a matéria dos pensamentos e percepções que alimentam a escrita nos diversos registros e que parecem surgir de um repositório sombrio.

Os heróis dos três romances, por exemplo, repassam com ansiedade os papéis e os feitos próprios e das outras personagens com as que interatuam, em espaços às vezes misteriosos ou povoados por fantasmas, em lugares heterotópicos onde desfilam seus fracassos e derrotas. Desse ponto de vista, contudo, que são esses fantasmas se não corporizações de espíritos artísticos ou emocionais, criativos, manifestações da imaginação, que passam, de alguma forma, a se enquistar nos narradores que são os sujeitos que conduzem o relato, mas que perdem ou entregam, aos poucos, esse poder? Trata-se, afinal, de narrações com equilíbrios temáticos instáveis na sua construção, mas de escrita firme na condução da inconsistência e volubilidade das personagens e que por isso mesmo traduzem assim a precariedade da vida.

Nos três romances, os autores privilegiaram destacar um exercício de memória que deixa ver a tentativa de driblar ou de amenizar a impossibilidade de esquecimento, que se traduz em reconhecimento obsessivo de imagens do passado que persistem como uma incisiva intervenção no presente da narração. Essa oscilação presente/passado é uma marca de estilo bastante pronunciada nos textos aqui comentados, com diferenças significativas entre eles. A breve menção ao ano 2001 como um ano negro e as referências a uma sociedade que está se corrompendo até o ponto de que os desperdícios comecem a dar o tom relevante do aspecto das cidades e do campo, em El desperdicio marca uma diferença com os outros dois textos nos quais não há referências diretas a situações políticas do presente. A vastidão de conhecimentos variados que domina o narrador de Amsterdam e sua inteligência assimilativa é um diferencial de Ian McEwan em toda sua obra. A concepção da literatura como um espaço para a recreação verbal e para exercer o poder da língua escrita para dar conta da natureza em sua mais potente realidade parece ser a melhor e mais notória característica de Los ingrávidos.

No entanto, por mais que um realismo performático traspasse e estruture os três livros não é menor o peso que têm as fraudes, os plágios e as falsificações nas sucessivas camadas de discursos que vão fazendo com que o verdadeiro fique oculto e inacessível, apesar da sofisticada consciência cênica que os autores revelam na construção dos romances. Talvez a condição de vítima de plágio de Elena, a decisão de fraudar um documento da narradora da Los ingrávidos e o final de estrondoso plágio de Clive revelem mais das aflições da contemporaneidade - entre o impulso criativo, os avanços tecnológicos e as turvações narcísicas - que as possíveis menções a sucessos 
históricos nos textos, o que poderia se considerar como uma poderosa marca de performatividade reflexiva bastante característica do século XXI. Observe-se, não obstante, que, à diferença de Amsterdam e de El desperdicio, a única mimese concreta que temos nos três romances é a parte da deliberada recuperação da obra de Owen em Los ingrávidos, apesar do desafio ao realismo que implica o compromisso com o fantástico-biográfico que caracteriza o romance de Luiselli.

Ressalte-se que são, também, histórias de renascimento, de viver de novo em mundos outros, de morrer muitas mortes e de seguir vivendo, como diz a narradora de Los ingrávidos, como se a vida consistisse em perambular entre diversas heterotopias, sem separações radicais entre um mundo e outro, entre o conhecido e o novo, o humano e o sobrenatural, o concreto e o fantasmagórico, o real e o onírico, passagens essas que não se sabe como evoluirão, não obstante todo o desconforto que isso produza nos leitores. A leitura aqui empreendida de três textos distantes, de acordo com quase todos os parâmetros possíveis de comparação, menos o temporal porque foram publicados dentro de um breve intervalo de tempo, foi uma tarefa que requereu organizar os textos para selecionar os momentos que pareceram significativos segundo uma lógica de paralelismo exemplificador, ainda que, de resto, é também por onde se podem apreender ressonâncias inesperadas e distâncias insuperáveis entre os livros.

\section{REFERÊNCIAS}

FOUCAULT, Michel. Outros Espaços. Motta, Manoel Barros da (org.): Michel Foucault: Estética: Literatura e pintura, música e cinema. Ed. Forense Universitária. Rio de Janeiro e São Paulo. Disponível em <http://escolanomade.org/wpcontent/downloads/foucault-de-outros-espacos.pdf 17/02/2019>

KANZEPOLSKY, Adriana. La memoria justa y las promesas incumplidas: El desperdicio de Matilde Sánchez. Alea, Rio de Janeiro, v. 15, n. 1, p. 184200, June 2013. <http://www.scielo.br/scielo.php?script=sci_arttext\&pid=S1517106X2013000100012\&lng=en\&nrm=iso> Acesso em 18 fev. 2019.

LUISELLI, Valeria. Los ingrávidos. Madrid: Sexto Piso, 2011.

McEWAN, Ian. Amsterdam. São Paulo: Companhia das Letras, 2012.

SÁNCHEZ, Matilde. El desperdício. Buenos Aires: Aguilar, Altea, Taurus, Alfaguara, 2007. 
